\title{
EFFECT OF ALCOHOL AND KOLANUT INTERACTION ON BIOCHEMICAL INDICES OF NEURONAL GENE EXPRESSION IN WISTAR ALBINO RATS
}

\author{
G. O. OBOCHI ${ }^{1}$, A. E. ABARA ${ }^{1}$, S. P. MALU ${ }^{1}$, V. S. EKAM ${ }^{2}$, F. U. UBOH ${ }^{2}$, and \\ I. B. $\mathrm{UMOH}^{2}$ \\ ${ }^{1}$ Department of Biochemistry, Cross River University of Technology, Calabar. \\ ${ }^{2}$ Department of Biochemistry, University of Calabar. \\ E-mail: gobochi@yahoo.com Tel: +234 8052707200
}

\begin{abstract}
Summary: Effect of alcohol and kolanut interactions on biochemical indices of neuronal gene expression in Wistar albino rats was studied. Thirty Wistar albino rats were divided into six groups of five (5) rats per group. The control group (1) received via oral route a placebo (4ml of distilled water). Groups 2 - 6 were treated for a period of 21-days with $(10 \% \mathrm{v} / \mathrm{v}) 50 \mathrm{mg} / \mathrm{kg}$ body weight of alcohol, $50 \mathrm{mg} / \mathrm{kg}$ body weight of kolanut, $50 \mathrm{mg} / \mathrm{kg}$ body weight of caffeine, $50 \mathrm{mg} / \mathrm{kg}$ body weight of alcohol and $50 \mathrm{mg} / \mathrm{kg}$ body weight of kolanut, and $50 \mathrm{mg} / \mathrm{kg}$ body weight of alcohol and $50 \mathrm{mg} / \mathrm{kg}$ body weight of caffeine in $4.0 \mathrm{ml}$ of the vehicle via gastric intubation respectively. One day after the final exposure, the brain of each rat was harvested and processed to examine several biochemical parameters, i.e., total protein, DNA, RNA and protein/RNA ratios. The status of neuronal gene expression was monitored through assessment of these parameters. The results showed that alcohol-kolanut co-administration decreased brain total protein, DNA, RNA levels and protein/RNA ratios, and inhibited gene expression. These effects, in turn, inhibited DNA transcription, MRNA splicing and protein synthesis, and polypeptide expression, which are necessary for the growth, development, differentiation and cell survival.
\end{abstract}

Key Words: Alcohol, Kolanut, Gene expression, DNA, RNA, Protein.

\section{Introduction}

Alcohol and Kolanuts are common items of entertainment in community functions. Kolanut contains constituents, which include kolanin, quinine, caffeine, theobromine and theophylline (Adeyeye and Ayejuyo, 1994; Eteng et al, 1992; Abulude, 2004; Obochi, 2006). These constituents are also constituents of coffee, cocoa and tea leaves and are widely consumed through their beverages such as snacks (coke, schwepps, bitter lemon, etc), pharmaceutical products, over the counter drugs, and extracts of coffee, cocoa and kolanuts (Eteng, et al, 1997; Abulude, 2004; Obochi, 2006). Alcohol is widely consumed through alcoholic beverages such as table wines, beers, desert or cocktail wines, cordials, liquors, whisky and brandy. These beverages (alcohol and kolanuts) are valued as foods, medicine and ceremonial drinks. Although, negligibly nourished, alcohol is an energy producing food like sugar (El-mas et al, 1994; Dorhman et al, 1997; Fadda \& Rossetti, 1998; Koobs et al, 1998; Lieber, 1999; 2000; and Danbolt, 2001). These drugs (alcohol and kolanuts) have opposing effects on the brain. Brain function involves subtle chemical and electrical processes, which can easily be altered and modified with the use of psychoactive drugs (Obochi, 2006).

Gene expression is linked with an interplay of neurotransmitter uptake during DNA transcription, mRNA splicing and degradation together with protein synthesis, and polypeptide expression. Organisms, including humans adapt to environmental changes by altering gene expression. The regulation of the expression of the genes is necessary for the growth, development, differentiation and the very existence of the organism. The process of alteration of gene expression involves the interaction of specific binding proteins such as nerve growth factors, glial derived neurotrophic factors, peptides, etc, with various regions of DNA in the immediate vicinity of the transcription site (Obochi, 2006). The composite of these induced changes in gene expression may result in the cellular responses to tolerance and dependence and may lead to neuronal dysfunction. Thus, the metabolic 
interaction between alcohol and kolanut may be of medical importance for diagnosis and or treatment of neuronal disorders.

\section{Materials and Methods}

\section{Experimental Animals}

Thirty (30) Wistar albino rats weighing between $150-280 \mathrm{~g}$ obtained from the disease free stock of the animal house, Department of Biochemistry, College of Medical Sciences, University of Calabar, Nigeria were used for the study. The animals were randomly assigned into six (6) groups of five (5) animals per group. Each rat in a study group was individually housed in a stainless cage with plastic bottom grid and a wire screen top. The animal room was adequately ventilated, and kept at room temperature and relative humidity of $29 \pm 2^{0} \mathrm{c}$ and $40-70 \%$ respectively with 12 hour natural light-dark cycle. The animals were fed ad libitum with water and rat chow (livestock feeds Ltd, Calabar, Nigeria). Good hygiene was maintained by constant cleaning and removal of faeces and spilled feed from cages daily.

\section{Treatment Regimen}

The control group (1) received via oral route (oral gavage) a placebo ( $4 \mathrm{ml}$ of distilled water). Groups 2 to 6 were treated for a 21-day period with $(10 \% \mathrm{v} / \mathrm{v}) 50 \mathrm{mg} / \mathrm{kg}$ body weight of alcohol, $50 \mathrm{mg} / \mathrm{kg}$ body weight of kolanut, $50 \mathrm{mg} / \mathrm{kg}$ body weight of caffeine, $50 \mathrm{mg} / \mathrm{kg}$ body weight of alcohol and $50 \mathrm{mg} / \mathrm{kg}$ body weight of kolanut, and $50 \mathrm{mg} / \mathrm{kg}$ body weight of alcohol and $50 \mathrm{mg} / \mathrm{kg}$ body weight of caffeine in $4.0 \mathrm{ml}$ of the vehicle via gastric intubation (ie, orally using orogastric tubes and syringes) respectively. The experiments were conducted between the hours of 9.00am and 10.00am daily.

\section{Preparation of Caffeine}

Synthetic caffeine was obtained from May and Baker (M\&B) limited, Enfield, Middle Sex, United Kingdom, and used for the study. A stock solution of caffeine was prepared by dissolving $20 \mathrm{~g}$ of powder caffeine in $500 \mathrm{ml}$ of hot distilled water. The solution was allowed to cool to room temperature, and $50 \mathrm{mg} / \mathrm{kg}$ body weight of caffeine was administered to groups 4 and 6 in $4.0 \mathrm{ml}$ of the vehicle via gastric intubation.

\section{Preparation of Kolanut:}

Kolanuts were obtained from the Bogobiri market, Calabar, Nigeria and used for the study. The kolanuts were washed, an dried at $60^{\circ} \mathrm{c}$ for 12 hours, and ground using electric kenwood blender. $20 \mathrm{~g}$ of the kolanut was dissolved in $500 \mathrm{ml}$ of hot distilled water. Out of the stock solution prepared $50 \mathrm{mg} / \mathrm{kg}$ body weight was administered to the animals in groups 3 and 5 in $4.0 \mathrm{ml}$ of the vehicle via gastric incubation.

\section{Preparation of Alcohol}

The alcohol used was distilled from palm wine (Elias guinensis) using quick fit distillation apparatus. $10 \% \mathrm{v} / \mathrm{v}$ of the alcohol was prepared and $50 \mathrm{mg} / \mathrm{kg}$ body weight of alcohol was administered to the animals in groups 2,5 and 6 in $4.0 \mathrm{ml}$ of the vehicle via gastric incubation.

\section{Sample Preparation}

One day after the final exposure, the animals were anaestheticized by inhalation of an over dose of chloroform, and the brain of each rat was harvested, ground using mortar and pistle, and buffered with TRIS-HCL buffer, $\mathrm{pH}$ 7.4. A whole homogenate (WH) was prepared by centrifugation $(4000 \mathrm{xg}, 30$ minutes). The supernatant was again centrifuged at $6000 \mathrm{xg}$ for 20 minutes and made up to $100 \mathrm{ml}$ mark with the TRIS-HCL buffer, pH 7.4 in a volumetric flask. The whole homogenate thus obtained was stored at $-70 \%$ in the freezer and used for the various assays.

\section{Biochemical Assays:}

The whole homogenate (WH) obtained was used for the analysis of brain total protein, DNA and RNA levels. Brain protein/RNA ratios were calculated. Brain total protein was determined by the Biuret method described by Lowry et al (1951), which represents the modifications of Gornall et al (1949). DNA and RNA were determined by the Diphenylamine and Orcinol assays respectively described by Burton (1956). Brain protein/RNA ratios were calculated.

In protein analysis, $1.5 \mathrm{ml}$ of the whole homogenate was measured and $0.2 \mathrm{ml}$ of $5 \%$ sodium deoxycholate (Doc) in $0.01 \mathrm{~N} \mathrm{KOH}$ was added, and mixed. Then, $1.5 \mathrm{ml}$ of the Biuret reagent $\left(1.5 \mathrm{og} \mathrm{CuSo}_{4} .5 \mathrm{H}_{2} \mathrm{O}, 6.0 \mathrm{~g}\right.$ sodium potassium tartrate, and $300 \mathrm{ml}$ of $10 \% \mathrm{NaoH}$ per L) was added and mixed. The tubes were incubated for $15 \mathrm{~min}$ at $37^{\circ} \mathrm{c}$ and the absorbances were read at $540 \mathrm{~nm}$ against a reaction blank in a spectrophotometer.

In DNA analysis (Diphenylamine assay), $2.0 \mathrm{ml}$ of the whole homogenate (WH) was measured and $2.0 \mathrm{ml}$ of the diphenylamine reagent (Dissolved $0.7 \mathrm{~g}$ of diphenylamine in $50 \mathrm{ml}$ of glacial acetic acid and $0.75 \mathrm{ml}$ of conc. $\mathrm{H}_{2} \mathrm{So}_{4}$ was added. 
Just prior to use, $0.25 \mathrm{ml}$ of cold $1.6 \%$ acetaldehyde was added. [Prepared in a fume hoods]) the tubes were allowed to cool to room temperature and the absorbances were read at $600 \mathrm{~nm}$ against a reaction blank.

In RNA analysis (Orcinol assay), $0.5 \mathrm{ml}$ of the whole homogenate (WH) was measured and made up to $2.0 \mathrm{ml}$ with $5 \%$ trichloroacetic acid (TCA). Then $2.0 \mathrm{ml}$ of orcinol reagent (Dissolved $0.5 \mathrm{~g}$ of orcinol in $50 \mathrm{ml}$ of $0.1 \%$ $\mathrm{Fecl}_{3}$ in conc. Hcl. [prepared in a fume hood]) was added and mixed. The orcinol reagent was prepared just prior to use. The tubes were heated in a boiling water bath for 15 minutes. The tubes were removed and allowed to cool to room temperature and the absorbances were read at $640 \mathrm{~nm}$ against a reaction blank in a spectrophotometer.

Statistical Analysis

Data collected were expressed as mean \pm standard deviation (SD), analysis of variance
(ANOVA) and the student ' $\mathrm{t}$ ' test were used for analysis. Values of $\mathrm{p}<0.05$ were regarded as significant.

\section{Results}

Table 1 presents the results of the effects of the treatment on brain total protein, DNA, RNA and Protein/RNA ratio levels in wistar albino rats. The results showed that kolanut and caffeine independently produced a non significant increase $(\mathrm{P}<0.05)$ in values of the total protein, DNA, RNA and Protein/RNA ratios relative to control while alcohol had a contrary effect. However, co-administration of alcohol and kolanut as well as alcohol and caffeine produced a significant decrease $(\mathrm{P}<0.05)$ in values of the total protein, DNA, RNA and Protein/RNA ratios relative to control. These results showed that alcohol suppressed the effects of kolanut and caffeine.

Table 1: Effect of treatment on brain total protein, DNA, RNA and Protein/RNA ratio levels in wistar lbino rats.

\begin{tabular}{llllll}
\hline & \multicolumn{5}{c}{ Parameters } \\
\hline & $\begin{array}{c}\text { Group } \\
(\mathrm{N})\end{array}$ & $\begin{array}{c}\text { Brain total } \\
\text { protein } \\
(\mathrm{mg} / \mathrm{ml})\end{array}$ & $\begin{array}{c}\text { Brain total } \\
\text { DNA } \\
(\mathrm{mgDNA} / \mathrm{ml})\end{array}$ & $\begin{array}{c}\text { Brain total } \\
\text { RNA } \\
(\mathrm{mgRNA} / \mathrm{ml})\end{array}$ & $\begin{array}{c}\text { Brain } \\
\text { Protein/RNA } \\
\text { ratio }\end{array}$ \\
\hline 1. & Control & $9.83 \pm 0.63$ & $5.39 \pm 0.88$ & $6.65 \pm 0.48$ & $1.48 \pm 1.31$ \\
2. & Alcohol & $6.74 \pm 0.48^{*}$ & $4.89 \pm 0.41^{*}$ & $6.34 \pm 0.35^{*}$ & $1.06 \pm 1.37^{*}$ \\
3. & Kolanut & $12.46 \pm 0.57^{*}$ & $8.93 \pm 0.69^{*}$ & $6.54 \pm 0.75^{*}$ & $1.90 \pm 0.76^{*}$ \\
4. & Caffeine & $14.25 \pm 0.62^{*}$ & $10.28 \pm 0.87^{*}$ & $6.24 \pm 0.78^{*}$ & $2.28 \pm 0.80^{*}$ \\
5. & Alcohol- & $7.48 \pm 0.63^{*}$ & $5.27 \pm 0.67^{*}$ & $6.26 \pm 0.43^{*}$ & $1.20 \pm 2.86^{*}$ \\
& $\begin{array}{l}\text { Kolanut } \\
\text { 6. }\end{array}$ & & & & \\
& Alcohol- & $8.48 \pm 0.67^{*}$ & $5.86 \pm 0.58^{*}$ & $6.38 \pm 0.41^{*}$ & $1.30 \pm 1.46^{*}$ \\
\hline
\end{tabular}

* Significantly different from control, $P<0.05$ using ANOVA and student ' $t$ ' test.

Values are expressed as mean $\pm S D, N=$ Number of rats per group $=10$

\section{Discussion}

In this study, kolanut and caffeine were independently found to increase total protein, DNA and RNA levels and Protein/RNA ratio while alcohol, alcohol-kolanut and alcoholcaffeine decreased total protein, DNA and RNA levels and Protein/RNA ratio. The results showed that kolanut acted synergistically with alcohol to decrease total protein, DNA and RNA levels, and Protein/RNA ratio. The results of this study agreed with earlier studies of Mackler and Eberwine (1991), Snyder et al (1992), Baek et al (1994), Kim et al (1996), Bonner et al (1996), Miller (1996) and McAlhany et al (2000). The reports of these workers showed that the depressant actions of alcohol interfered with synthetic processes hence a reduction in total protein, DNA and RNA, with the overall effect on the reduction in the cell number and neurophil volume, alteration of myelin formation due to interference with protein synthesis. This could suggest that the mechanism of alteration in rat brain protein synthesis might involve interaction of the brain polysomes with alcohol, with a resultant alteration in messenger RNA components associated with the ribosomal units, which are used for protein biosynthesis. The overall effect was the decrease in Protein/RNA ratio, an index of gene expression (Schafer et al 2001). The process of alteration of gene expression involves the interaction of specific binding proteins with the various regions of DNA in the vicinity of the transcription site and 
this produces either a positive or negative effect of transcription (Snyder et al, 1992; Keeton et al, 1993; Johnson and Barford, 1993; Granner, 1996). This could be attributed to the suppression of the metabolic processes by alcohol, thereby inhibiting gene transcription signal transduction and protein synthetic pathways, in parts, through competition for a common microsomal detoxification process due to the interference of alternative pathways (mostly the microsomal ethanol oxidizing systems - MEOS) (Snyder et al, 1992; Phung and Black, 1999; Lieber, 1999; 2000; Lindgreen, 2001; Danbolt, 2001; Obochi, 2006).

The neurodegenerative actions of alcohol as expressed in depletion of total protein, DNA and RNA levels might be derived from its reduction of available nerve growth factor receptors, which were responsible for the cell survival, development and differentiation, resulting in the modulation of neurotransmitter uptake at the level of DNA transcription, mRNA splicing and degradation together with protein synthesis (Baek et al, 1994; Dohrman et al, 1997; Fadda and Ropssetti, 1998; elman et al, 1999; Heaton et al, 2000; Schafer et al, 2001).

Conclusively, alcohol - kolanut interactions depressed neuronal function and inhibited gene expression, leading to an impairment in growth, development, differentiation and could potentiate a risk to tolerance and dependence.

\section{References}

Abulude, F. O. (2004). Composition and Properties of kola nitida and kola nitida flour in Nigeria. Global Journal of Pure and Applied Science, 10 (1), 11 - 16.

Adeyeye, E. I. and Ayejuyo, O. O. (1994). Chemical composition of kola acuminate and Garcina kola seeds grown in Nigeria. International Journal of food Science and Nutrition, 45, 223-230.

Baek, J. K., Heaton, M. B. \& Walker, D. W. (1994). Chronic Alcohol ingestion: Nerve growth factor gene expression and neurontrophic activity in rat hippocampus. Alcohol Clinical Experimental Research, 18(6): 1368-1376.

Bonner, A. B., Marway, J. S., Swann, M. \& Preedy, R. (1996). Brain nucleic and composition and fractional rates of protein synthesis in responses to chronic ethanol feeding: comparisonw ith skeletal muscle. Alcohol, 13 (6): 581-587.

Burton, K. (1956). Determination of DNA and RNA contents of an isolated DNA and RNA products. Journal of Biochemistry, $62,315-323$.
Danbolt, N. C. (2001). Glutamate uptake. Journal of Neurobiology, 65(1), 100-105.

Dorhman, D. P., West, J. R. and Pantazis, N. J. (1997). Ethanol reduces expression of the nerve growth factor receptors, but not nerve growth factor protein levels in the neonatal rat cerebellum. Alcohol Clinical Experimental Research, 21(5), 882-893.

Elman, I., Godlstein, D. S., Eubsebgirm G., Folio, J., Makgitram A. K., Adler, C. M., Pickar, D. and Breier, A. (1999). Neurodegenerative Mechanisms of Alcohol actions. Neuropsychopharmacology, 20: 29-34.

El-mas, M. M., Tao, S., Carrol, R. G. and Abdel-Rahman, A.A. (1994). Role of alcohol on central nervous system, Alcohol, 11, 307-314.

Eteng, M. U. Eyong, E. U. Akpanyong, E. O. Agiang, M. A. and Aremu C. Y. (1997). Recent Advances in caffeine and theobromine toxicities: A review. Plant Food for Human Nutrition, 51, 231 - 243.

Fadda, F. and Rossetti, Z. L. (1998). Chronic ethanol consumption: From Neuroadaption to neurodegeneration. Journal of Neurobiology, 56(4), 385-431.

Granner, D. K. (1996). Regulation of gene expression,in: Harper's Biochemistry $\left(24^{\text {th }}\right.$ Edn), pp. 447-464. Appleton \& Lage, USA.

Gornall, A. G. Bardawill, C. J. and Maxima, D. (1949). Determination of Serum protein by means of the Biuret reaction. Journal of Biological Chemistry, 177: 751 - 766.

Heaton, M. B., Mitchell, J. J., Paiva, M. and Walker, D. W. (2000). Ethanol-induced alterations in the expression of neurotrophic factors in the developing rat control nervous system. Journal of Developmental Brain Research, 21(1): 97-107.

Johnson, L. N. and Barford, D. (1993). The effect of phosphorylation on the structure and functionof proteins. Annu. Rev. Biophys. Biomol. Struct. 22: 199-206.

Keeton, W. T., Gould, J. L. and Gould, C. G. (1993). Control of gene expression, In: Biological Science ( $5^{\text {th }}$ edn.) pp. 275-309. W.W. Norton \& Co. New York.

Kim, J. J., Shih, J. C., Chenk, c. L., Bao, S., Maren, S., Anagnastraras, S. G., Fanselow, M. S., De Meyer, E., Seif, I. and Thompson, R. F. (1997). Alcohol and neural function. Journal of Developmental Brain Research, 96 (1-2): 1-10.

Koobs, G. F., Roberts, A. J., Schulteis, G. Parsons, L. H, Heyser, C. J, Hyytia, P, Merlopich, E. and Weiss, F. (1998). Neurocircuitry targets of ethanol reward and dependence. Alcohol, Clinical Experimental Research, 22(1), 3-9. 
Lindgreen, U. (2001). High alcohol concentration in blood rat resulted in massive apoptosis. Lakartidningen, 98 (5): 445-450.

Lieber, C. S. (1999). Interaction of ethanol with drugs, hepatic agents, carcinogens and vitamins. Alcohol, Alcoholism, 25,157-176.

Lieber, C.S. (2000). Pathway of ethanol metabolism and related pathology. In T.N. Palmer (ed). Alcoholism: A molecular perspective (pp.1-25). New York: Plenum Press.

Lowry, O. H, Rosenbrough, N. J, Farr, A. L and Randau, R. J (1951). Protein measurement with the folin phenal reagent. Journal of Biological Chemistry, 193: 265 $-275$.

Mackler, S. A. and Eberwine, J. H. (1996). The molecular biology of additive drugs. Molecular Neurobiology, 5 (1): 45-58.

McAlhany, R. E. J., West, J. R., Miranda, R. C. (2000). Glial-derived neurotrophic factor (GDNF) prevent ethanol-induced apoptosis and JUN Kinase phosphorylation. Journal of Developmental Brain Research, 119(2): 209-216.
Miller, M. W. 91996). Effect of early exposure to ethanol on the protein and DNA contents of specific brain regions in the rat. Brain Research, 734 (182): 286-294.

Obochi, G. O (2006). Effect of alcohol-kolanut interaction on biochemical indices of neuronal function and gene expression in wistar albino rats. A Ph.D. Thesis submitted to the Graduate School, University of Calabar - Nigeria.

Phung, Y. T. and Black, S. M. (1999). The synergistic action of ethanol and nerve growth factors in the induction of neuronal nitric oxide synthetase. Alcohol, 34 (4): 506-510

Schafer, G. L., Crabbe, J. C. and Wirren, K. M. (2001). Ethanol regulated gene expression of neuroendocrine specific protein in mice: Brain region and genotype specificity, Brain Research, 897 (1\&2): 139-149.

Snyder, A. K., Singh, S. P. and Ehmann, S. (1992). Effect of ethanol on DNA, RNA and protein synthesis in rat astrocyte cultures. Alcohol Clinical Experimental Research, 16 (2): 295-300.

Received: $22 / 5 / 2007$

Accepted: 9/8/2007 